\title{
適応制御を用いた多軸速度同期システム*
}

\author{
鎌野㙇也 也 $^{* *}$ 鈴木茂行**・飯田賢—** \\ 片岡, 雄 ${ }^{* * *}$ ・富塚誠 義 ${ }^{* * * *}$
}

\section{Multiple Axes Synchronizing System under Adaptive Feedforward Control*}

Takuya Kamano**, Takayuki SuzukI**, Kenichi IIDA**, Yu KATAOKA ${ }^{* * *}$ and Masayoshi TomizuKA ${ }^{* * * *}$

\section{1.はしがき}

抄紙機，工作機械，巻取り機などのように, 動特性の異なる複数の駆動軸を有するプラント においては, 製品精度あるいは作業効率の向上 のために, 軸間の同期化を図りつつ, 各軸の回 転速度を精密に制御する必要がある1 ながら, 動作条件によりその動特性が, 変動す る駆動軸の回転速度を, 定常状態のみならず過 渡状態に扔いて同期させることは，固定ゲイン コントロールを用いる従来の制御システムでは 限界があり，適応機能を有する同期化コントロ 一ラが必要となる.

本論文では，アダプティブフィードフォワー ドコントローラ $(\mathrm{AFC})^{2)}$ と同期化コントロー ラを組み合わせた, 二軸速度同期システム ${ }^{3), 4)}$ を多軸システムに拡張した，多軸速度同期シス テムを提案する．同システムの応答特性のシミュ レーション結果から，その有用性が確認された ので，以下に報告する.

\section{2. システム構成}

Fig. 1 亿，提案する多軸速度同期システムの 構成図を示す．第 1 軸から第 $n$ 軸のプラント の動特性は, それぞれパラメータの異なる一次

* 原稿受付 1991. 11. 30

** 徳島大学 工学部 The University of Tokushima ; 2-1 Minamijosanzima, Tokushima 770, JAPAN

*** 片岡機械製作所 Kataoka Machine Co., LTD ; 476546 Sangawa, Iyomishima 770, JAPAN

**** カリフォルニア大学 バークレー校 Department of Mechanical Engineering, University of California ; Berkeley, California, CA 94720, U.S.A

Key Words : multiple axes system, adaptive control, feedforward control, motion control, synchronization.

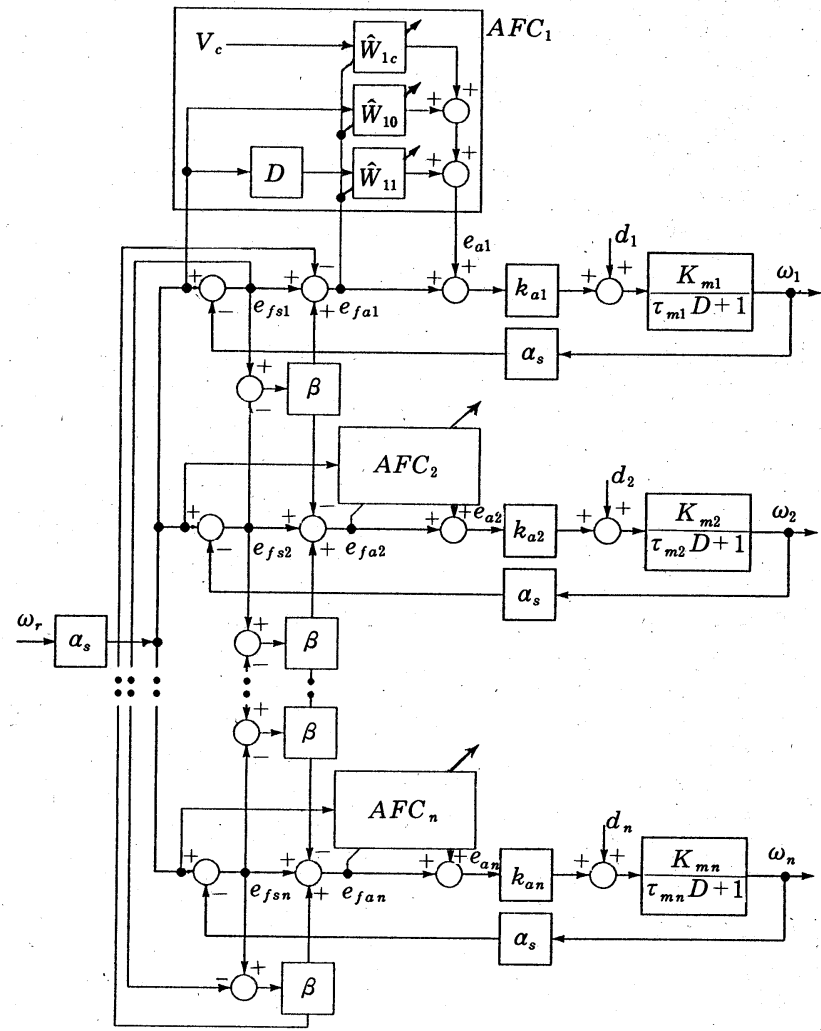

Fig. 1 Synchronizing adaptive feedforward control for multi-axes system

遅れ要素で表わし，各軸は，固定ゲインコントローラ $\left(k_{a i}\right)$ からなるフィードバックループを構成している.

各軸には, 他の軸之の同期化を図りつつ追従誤差を減 少させ, 応答性を改善するための $\mathrm{AFC}$ が設けられてい る: $\mathrm{AFC}$ の各パラメー夕は, 対応する軸の追従誤差信 号之, 同期化コントローラからの同期化誤差信号より求 められる適応誤差信号を用いて, 次式で調整される. 


$$
\frac{d \hat{\boldsymbol{P}}_{i}(t)}{d t}=\gamma e_{f a i}(t) \Phi(t)(i=1 \sim n)
$$

ここで, $\hat{\boldsymbol{P}}_{i}(t)$ は次式で表わされる適応パラメータベク トルであり,

$$
\hat{\boldsymbol{P}}_{i}^{T}(t)=\left[\hat{W}_{i 1}(t), \hat{W}_{i 0}(t), \hat{W}_{i c}(t)\right]
$$

$\gamma>0$ は適応ゲイン, $e_{f a i}(t)$ は適応誤差信号である. ま た， $\Phi(t)$ は次式で表わされる AFC の入力信号で

$$
\Phi^{T}(t)=\left[D \omega_{r}(t) \alpha_{s}, \omega_{r}(t) \alpha_{s}, V_{c}\right]
$$

$\omega_{r}(t)$ は規範入力, $V_{c}$ は一定入力, $\alpha_{s}$ は速度検出器の 係数, $D$ は微分演算子を表わす。第 $i$ 軸の適応誤差信号 $e_{f a i}(t)$ は，追従誤差信号と同期化コントローラからの 同期化誤差信号を用いて, 次式で求められる.

$$
\begin{aligned}
e_{f a i}(t)= & e_{f s i}(t)+\beta\left\{e_{f s i}(t)-e_{f s(i+1)}(t)\right\} \\
& -\beta\left\{e_{f s(i-1)}(t)-e_{f s i}(t)\right\} \\
= & (1+2 \beta) e_{f s i}(t)-\beta\left\{e_{f s(i+1)}(t)+e_{f s(i-1)}(t)\right\}
\end{aligned}
$$

こてで， $\beta>0$ は同期化パラメータである. (4) 式から 明らかなように，各軸は同期化コントローラを介して， 間接的に影響を及ぼし合い，その適応パラメータは，隣 合う軸間との同期化を図りつつ，追従誤差汃減少するよ う調整されている．本適応システムの漸近安定性は，超 安定論 5) を用いて証明される. ただし， $\beta=0$ とすると 同期化コントローラは作用せず，各軸は独立して動作す ることに注意しておく。

\section{3. 応答特性}

提案した多軸速度同期システムの一例として，六軸シ ステムの応答特性のシミュレーション結果から, その有 用性を確かめる．計算には Table 1 に示す時定数とゲ イン定数を用いるが，その值は未知の值として取り扱う. また，適応ゲイン $\gamma$ を $\gamma=0.1$ とし，規範入力として周 期 $8(\mathrm{~s})$, 振幅 $150(\mathrm{rad} / \mathrm{s})$ の台形波状の信号を用い,

Table 1 Time constants and gain constants of six axes system

\begin{tabular}{c|c|c}
\hline$i$-th Axis & $\begin{array}{c}\text { Time Constant } \\
\tau_{m i}(\mathrm{~s})\end{array}$ & $\begin{array}{c}\text { Gain Constant } \\
K_{m i}(\mathrm{rad} / \mathrm{s} / \mathrm{V})\end{array}$ \\
\hline 1st Axis & 1.407 & 19.24 \\
\hline 2nd Axis & 0.844 & 19.24 \\
\hline 3rd Axis & 0.563 & 19.24 \\
\hline 4th Axis & 0.281 & 19.24 \\
\hline 5th Axis & 0.141 & 19.24 \\
\hline 6th Axis & 0.0563 & 18.89 \\
\hline
\end{tabular}

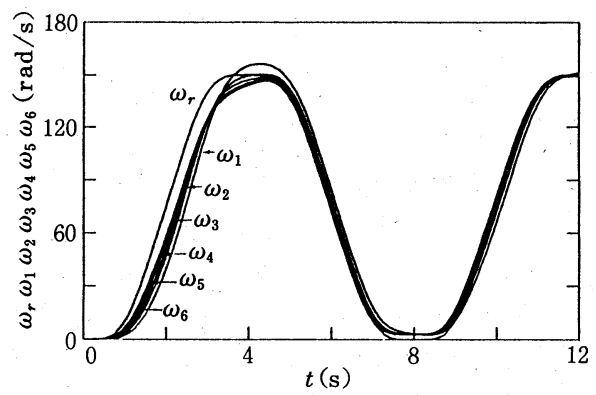

(a) Independent adaptive feedforward control ; $\beta=0$

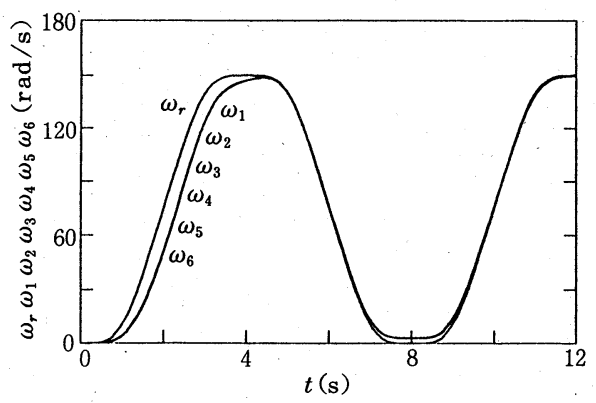

(b) Synchronizing adaptive feedforward control ; $\beta=20$

Fig. 2 Responses of six axes system in early stage of adaptation

各軸の固定ゲインコントローラの值 $k_{a i}$ はすべて 4 亿, 各適応パラメータの初期值は 0 にそれぞれ設定している.

Fig. 2 (a)，(b) は，それぞれ適応初期段階における $\beta=0$ と $\beta=20$ の場合の応答特性である. $\beta=0$ すると, 各軸は独立して動作するので, 各軸の出力は動特性の違 いから，それぞれ異る応答を示しつつ，規範入力に近づ いている. てれに対し， $\beta=20$ とすることにより各軸 出力は, 適応初期段階から一致して規範入力に近づいて いる. 乙の結果から, 各軸の動特性の違いは, 同期化コ ントローラにより補償されていることがわかる.

つぎに，適応後に，規範入力を一定に変更し，第 6 軸 のみに加えた外乱トルク $(0.1 \mathrm{Nm}$; 定格負荷トルクに 相当）に対するそれぞれ $\beta=0$ および $\beta=20$ の場合の応 答特性を, Fig. 3 (a), (b) に示す. $\beta=0$ の場合には, 外乱が加えられた軸の出力 $\omega_{6}$ のみが，その影響を受け 変化し, 他の軸の出力は, 規範入力に一致したままで ある. それゆえ，第6 軸の AFC の作用により，外乱の 影響が補償され， $\omega_{6}$ が規範入力に回復するまでの間, システムは非同期状態にある. 一方， $\beta=20$ とすると, 外乱が加えられた軸ばかりでなく，他の軸の出力む変 化し，過渡状態においても各軸の出力はほぼ一致してお り，高速の同期化が図られているてとがかわる.また， (4) 式から明らかなように, $\beta=20$ とすることは，適応 


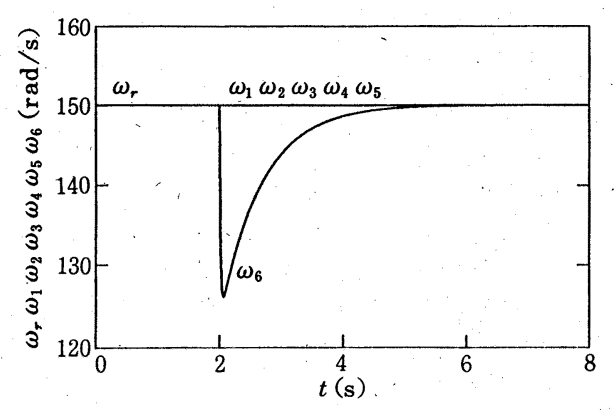

(a) Independent adaptive feedforward control; $\beta=0$

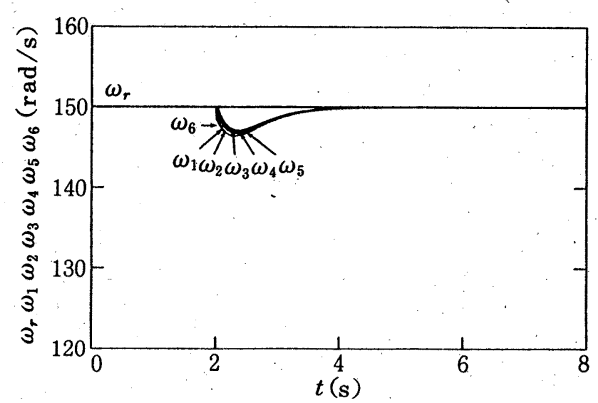

(b) Synchronizing adaptive feedforward control ; $\beta=20$

Fig. 3 Responses of six axes system to step disturbance to the sixth axis

ゲインを実質的に増加させることと等価であるため，同 一の外乱トルクに対する出力の変動幅は, $\beta=0$ の場合 に比較して減少している.

\section{4.むすび}

本論文では，適応制御を用いた多軸速度同期システム を提案している. 提案したシステムは，各軸に設けられ た適応コントローラ $(\mathrm{AFC})$ の適応䛊差信号之して，各 軸の追従誤差に加えて軸間の同期化誤差を導入するてと で，軸間の高速な同期化を実現している. こてでは一例 として, 六軸システムの応答特性のシミュレーション結 果から，その有効性を確かめた，その結果，本システム は動特性が未知であり, かつ, それらが大幅に異なる駆 動軸の出力を定常状態のみならず過渡状態に抢いても同 期させるてとができ; また, 外乱トルク変動に対しても, 高速の同期化の図れることが明らかとなった.

今後，提案システムの実装技術を検討し，実測結果か ら本システムの有用性を確認する予定である.

\section{参 考 文 献}

1) 電気学会 (編) : 電気工学ハンドブック:電気学会 (1988)

2) 鎌野, 鈴木, 井内, 富塚 : アダプティブフィードフォワー ド制御を用いた速度および位置制御システム；システム制 御情報学会論文誌, Vol. 4, No. 8, pp. 331 338 (1991)

3) M. Tomizuka, J.S. Hu, T.C. Chiu and T. Kamano: Synchronization of Two Motion Control Axes Under Adaptive Feedforward Control ; Adaptive and Learning Control, DSC-Vol. 21, pp. 1 8 (1990)

4) M. Tomizuka, T. Kamano and T. Suzuki : Design and Implementation of the Adaptive Synchronizing Feedforward Controller for Two Axes Motion Control Systems; IFAC International Symposium on ITAC, pp. 295 300 (1991)

5) I. D. ランダウ, 富塚：適応制御システムの理論と実際，才 - $\triangle$ 社 (1981) 